\title{
"Stimuli to adopt e-government services during Covid-19: Evidence from
}

Vietnam"

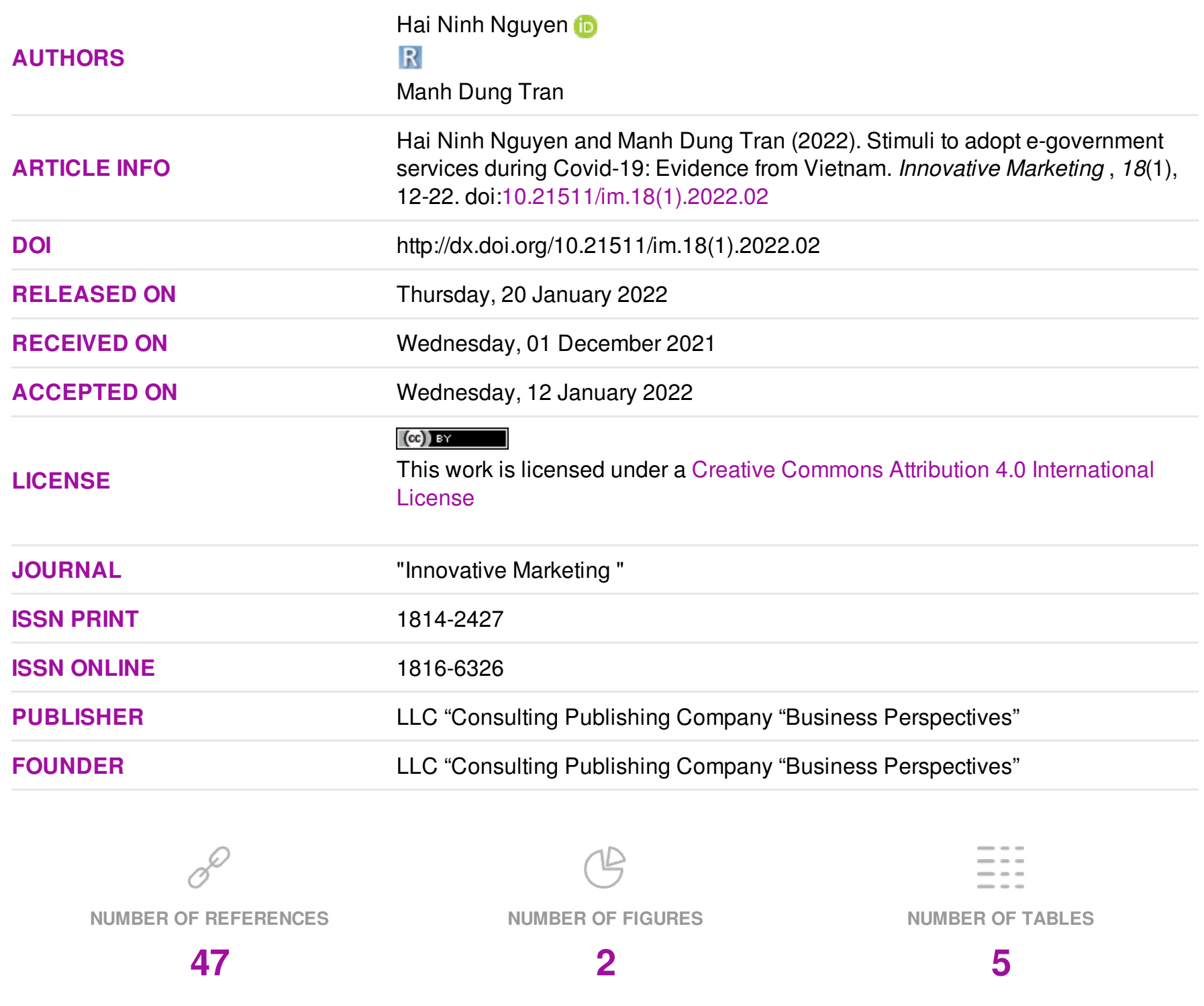

(C) The author(s) 2022. This publication is an open access article. 


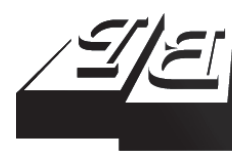

\section{BUSINESS PERSPECTIVES}

(O)

LLC "CPC "Business Perspectives" Hryhorii Skovoroda lane, 10, Sumy, 40022, Ukraine www.businessperspectives.org
Received on: $1^{\text {st }}$ of December, 2021 Accepted on: $12^{\text {th }}$ of January, 2022 Published on: $20^{\text {th }}$ of January, 2022

(c) Hai Ninh Nguyen, Manh Dung Tran, 2022

Hai Ninh Nguyen, Ph.D., School of International Business and Economics, Foreign Trade University (FTU), Vietnam. (Corresponding author)

Manh Dung Tran, Ph.D., Associate Professor, Journal of Economics and Development, National Economics University (NEU), Vietnam.

\section{STIMULI TO ADOPT E-GOVERNMENT SERVICES DURING COVID-19: EVIDENCE FROM VIETNAM}

\begin{abstract}
The goal of this study is to ascertain the critical elements affecting public acceptance and readiness to advocate electronic government services in Vietnam. An online survey was conducted among Vietnamese citizens. The chosen respondents had experience with e-government services. The analysis was utilized with the data gathered from 316 clean and legitimate responses. PLS-SEM analytic techniques and the SmartPLS program were adopted to execute analyzing processes. The findings indicate that three essential factors influenced the adoption of e-government services: (i) perceived service value, (ii) citizen e-empowerment, and (iii) fear of Covid-19. The perceived value of services, fear of Covid-19, and acceptance of e-government services all have a beneficial effect on citizen intention to recommend e-public services. This study suggested three practical implications: (a) leveraging the challenges of Covid-19 pandemic is to promote e-government services; (b) enhancing public service quality and informational quality is critical and vital to adopting e-government services, and (c) promoting citizen e-empowerment, outcomes, values, self-responsibility, and working procedures of e-public services to all citizens is necessary.
\end{abstract}

\section{Keywords e-government services, perceived service value, citizen e-empowerment, fear of Covid-19}

\section{JEL Classification $\quad$ M38, O32, 038}

\section{INTRODUCTION}

Digital innovation has been a critical driver for developing societies and economies in the $21^{\text {st }}$ century. According to the United Nations (2020), digital technologies have evolved faster than any other breakthrough in human history, reaching around $50 \%$ of the world's population in less than two decades. Throughout history, the industrial revolutions 1.0, 2.0, and 3.0 brought profound changes in production. In contrast, the fourth industrial revolution focuses on embedding the technologies in the societies and representing an entirely new way for people's connection and interaction. The whole community has been altered by improving immediate connection, allowing individuals to contact one another regardless of location or time. Digital transformation or government digitalization is one of the most important but not new phenomena. It goes back to the 1990s (Bellamy \& Taylor, 1998) under a different label - e-government. Although e-government was envisioned in the United States of America in 1993, it has since been accepted and developed globally, regardless of whether the country is developed, less developed, or developing.

At its core, e-government is the process of utilizing information and communication technology to provide public services to citizens or the process of utilizing ICTs to improve governance. Unlike the private sector, where businesses actively adopt the newest technologi- 
cal advances and apply them to their production, operation with the ideal hopes of optimizing and enhancing their operations, the public sector has still lagged because of bureaucracy and inefficiency. For decades, the digitalization of the public sector was the game of developed countries (OECD, 2019). The less developed and developing countries have not executed it due to investment costs and barriers of governmental traditions, citizens' knowledge, and even corruption. Additionally, before the Covid-19 pandemic, governments globally achieved significant technological advancements, although at a glacial rate. While some organizations had made tremendous strides, others were still in the early phases of digital transformation. When the world was struck by the Covid-19 pandemic, countries implemented public policies that included social isolation, self-quarantine, and social distance in response to the virus's spread. In terms of public service customers, people cannot come to public organization offices to take public services such as paying tax, registering the car, school enrolling for children, or checking the fine ticket. Hence, using technological applications is a robust solution to operate, govern, and keep everything as usual. The nature of service delivery has suddenly been changed: a traditional habit of relying on paper-based transactions has been replaced by new norms and practices of online marketing.

In recent years, local governments of developing countries have seriously considered implementing digital transformation for their operation and public service delivery for citizens and businesses. Vietnamese government identifies digital transformation as the critical motivation for the development and the shortest roadmap to catch up with developed economies. The national public service portal was launched in May 2020, which unites practically all citizens' public services into a single national online site, is one of the most critical pieces of proof supporting this initiative. As a country with a high proportion of internet users (via both computer and mobile devices) and smartphone owners, Vietnam seems quickly to achieve the target of fully implementing e-government. However, the reality is not along with the analysis data. Digitalization of the private sector shows rapid growth while the public service is still in the first stage.

\section{LITERATURE REVIEW}

Since the early 1990s, information technologies have been used to modernize public services in the US. Public organizations started email, internet forums, and official websites in public to communicate with citizens. However, as technology changes, electronic tools and applications support and boost communications between government offices and citizens. Email stays still while others have updated to the upper levels. Many countries have been working toward e-government with the primary purpose of offering efficient services to residents. As Ndou (2004) discusses, e-government minimizes bureaucracy. It delivers services to residents at all hours of the day or night and improves the service delivery quality including timeliness, substance, and accessibility.

E-government adoption has been documented and has continued to emerge in the literature (Kumar et al., 2007; Rehman et al., 2012).
E-government services usage is to get government information and conduct transactions through that site (Lean et al., 2009). The failure rate of e-government initiatives is extremely high due to a lack of citizen awareness, acceptance, and organizational deficiencies, with just $15 \%$ of government programs being successful (Rehman et al., 2012). There are two major streams of study on e-government adoption in the literature: citizen-centric research and government-office-centric research. From the citizen's perspective, perceived usefulness, convenience of use, performance expectation, effort expectation, social impact, enabling conditions, trust, risk perception, service/system/informational quality, attitude, subjective norm, and IT efficacy have been explored. Technological, organizational, institutional, and environmental variables have been explored from the government's standpoint.

According to Moore (1995), perceived public service value is the citizens' collective expecta- 
tions regarding government and public service. Twizeyimana and Andersson (2019) stated that private organizations serve customers for profit while government agencies serve people as a constituent. Governments are not tailored to the specific requirements of individuals; they have a direct influence on the public by assisting special interest groups (Castelnovo, 2013). Public organizations address the needs and desires of residents by delivering value. Beyond economic rewards, the government should consider political and social objectives while pursuing strategic goals. Inclusion, transparency, community regeneration, and stewardship are the pillars of public service efficiency (Grimsley \& Meehan, 2007). Bannister and Connolly (2014) argue that governments should digitally alter conventional public services to increase the efficiency with which they offer services to citizens and to make credit information available to the public via government websites and public portals.

Service quality is a common phenomenon in the business context and one of the traditional predictors of perceived service value, customer satisfaction, and behavioral intention. According to Frow and Payne (2007), to get a perfect customer experience, the quality-of-service delivery must be "perfect". Halvorsrud et al. (2016) supported this idea by confirming the relationship between the public service quality and customers' perceived emotions throughout their buying journey. Grönroos (1984) added the technical aspect to service quality; then, the service quality could be accessed from both the service approach and system approach. Without a doubt, the quality of e-public services is a critical problem in the digital public service industry (Jaradat et al., 2018).

An individual's assessment of the accuracy and usefulness of government information is referred to as its "information quality" (McKenney et al., 2002). They might be laws, legal papers, government reports, and notifications. Governments traditionally deliver the information to their citizens via paper documents, but this method is insufficient and not cost-effective. Therefore, citizens can easily access the information and recall the history data from government websites, which seem impossible in traditional format. According to Hung et al. (2006), the quality of information offered by e-government is determined by its correctness, currency, dependability, and accessibility. Additionally, Mensah (2019) asserts that when individuals have a favorable view of the government's ability and e-government performance, they will suggest it to others.

Citizen empowerment is a vague term rooted in psychological theory. Empowerment is described as the relationship between a sense of personal competence, a desire to participate in the public arena, and a readiness to act (Zimmerman \& Rappaport, 1988). Empowerment was established and commonly used to investigate workplace motives when Spreitzer (1995) introduced it in an economic research context (Ergeneli et al., 2007). Empowerment was used to assess the consumer's perceived desire to engage in the product's creation and subsequent decision-making. According to Peterson (2014), empowerment is comprised of four separate constructions that each have their own set of dimensions: competence, meaning, impact, and self-determination.

Competence is also referred to as self-efficacy (Bandura, 1986). Thomas and Velthouse (1990) describe it as a degree to which an individual possesses the necessary abilities to accomplish their occupation. The term "citizen e-empowerment" refers to a person who has been provided with the skills and information necessary to utilize e-government services.

Meaning is an individual's assessment of the worth of an activity considering his or her thoughts or standards (Thomas \& Velthouse, 1990). Thus, when individuals contact a government website to obtain a public service, they may utilize their perspective to assess the quality and worth of the services and information offered.

Impact is the extent to which a citizen's action is seen to have the desired repercussions or influence (Sjoberg et al., 2017). Thus, individuals may utilize the policies published on government websites to evaluate the activities and behaviors of members of the public community.

Self-determination was discussed by Turunen et al. (2020) as the sense of causal responsibility for an outcome resulting from citizen participation. 
Füller (2010) stated that the Internet and technology facilitate the empowerment of citizens in reinforcing individual identity and increasing efficiencies. Thus, this study proposed the term "citizen e-empowerment" with the meaning of citizen empowerment with e-government services. E-competence encompasses four dimensions: e-competence, e-meaning, e-impact, and e-self-determination. El-Haddadeh et al. (2021) investigated and validated the link between empowerment and people's perceived value of IOT - enabled intelligent devices in the public sector. Naranjo-Zolotov et al. (2019) used this theory to understand the influence of citizen empowerment on their desire to use e-participation. They demonstrated that citizen empowerment has a favorable effect on citizen intention to utilize e-participation.

To prevent the spreading of the Covid-19 pandemic, governments worldwide have adopted the social distancing policy that locks down the countries. Under social distancing policy, people must stay at home or reduce social gatherings. According to Wilder-Smith and Freedman (2020), because of closing schools/universities, public markets, and postponing, canceling activities and meetings, the social distancing requirement reduces group social contact, resulting in global isolation. Working from home and taking part in online activities instead of offline as in typical situations has been popularized and commonly accepted among people regardless of who they are, where they come from, and what they are doing. Fear is a sort of emotion that normally consists of three components spread over two dimensions (emotional reaction and physical experience, behavioral response, and physiological arousal).

Lu et al. (2016) defined intention to recommend as a type of post-adoption behavior, stressing the connection between service adoption and intention to recommend. Positive referrals from friends and family appear to be more convincing than marketing and advertising messages (Chen et al., 2004). Then, on the advice of relatives/friends, people may embrace technology. The loop introduces the technology to the general population without the need for advertisements. The association between service adoption and recommendation intention has been established in the business and technology literature (Oliveira et al., 2016; Shankar \& Datta, 2018; Mensah, 2019). According to Oliveira et al. (2016), a higher degree of adoption represents a higher level of referral intention to others. Additionally, Naranjo-Zolotov et al. (2019) corroborate the beneficial effect of e-participation adoption on the intention to suggest e-public services.

\section{AIMS AND HYPOTHESES}

This paper aims to explore the link between perceived public service value, citizen e-empowerment through e-government services, fear of Covid-19, adoption of e-government services, and

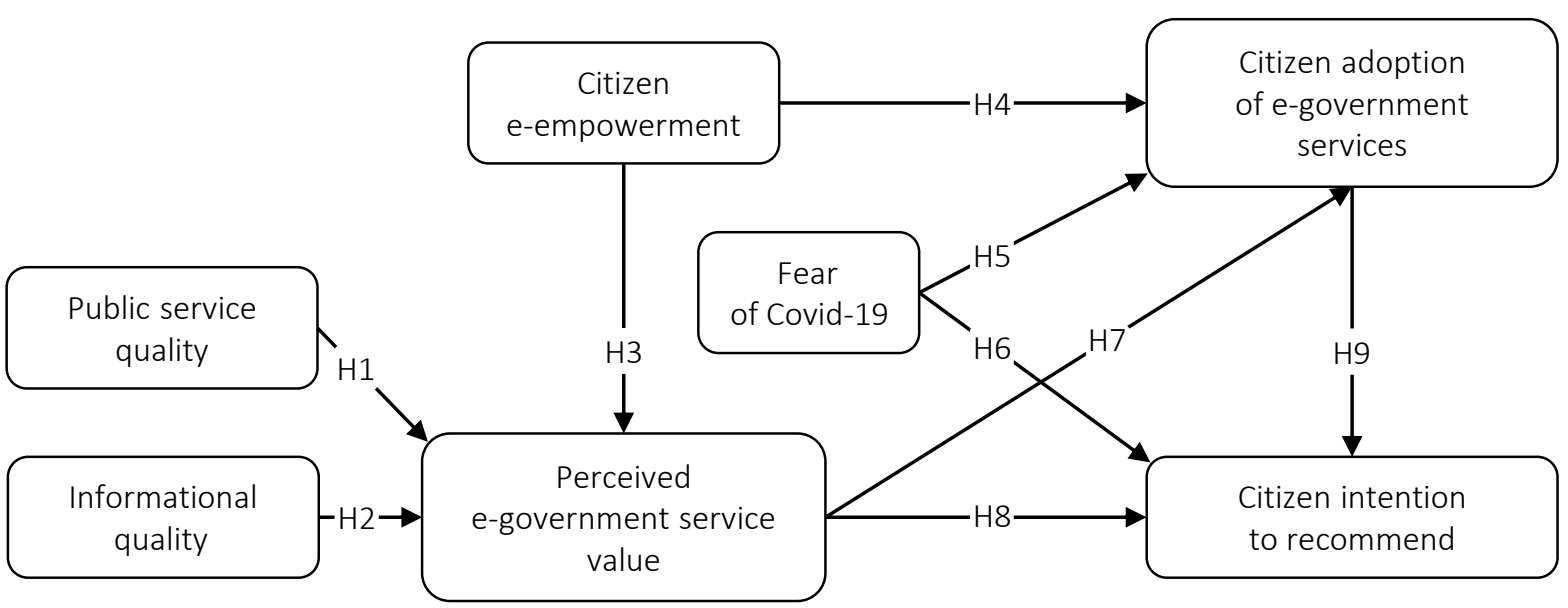

Figure 1. Research model 
citizen intention to recommend e-services. Hence, this study elaborated the research model and nine hypotheses (Figure 1).

H1: Public service quality has a significant impact on perceived public service value.

H2: Informational quality has a significant impact on perceived e-government service value.

H3: Citizen e-empowerment has a significant impact on perceived e-government service value.

H4: Citizen e-empowerment has a significant impact on citizen adoption of e-government services.

H5: Fear of Covid-19 has a significant impact on citizen adoption of e-government services.

H6: Fear of Covid-19 has a significant impact on citizen intention to recommend e-services.

H7: Perceived e-government service value has a significant impact on citizen adoption of e-government service.

H8: Perceived e-government service value has a significant impact on citizen intention to recommend e-services.

H9: Citizen adoption of e-government services has a significant impact on citizen intention to recommend e-services.

\section{METHODS}

The notion of e-government service adoption is drawn from the concepts of e-commerce/digital service adoption. The bulk of research has examined e-government service adoption through the lens of technology acceptance models, which originated from the theory of reasoned action (TRA), the theory of planned behavior (TPB), and the unified theory of acceptance and use of technology (UTAUT). Numerous determinants have been found and analyzed, including performance expectations, effort expectations, social impact and enabling conditions (UTAUT), as well as perceived utility and simplicity of use
(TAM). Shareef et al. (2011) proposed the e-government adoption model (GAM), which is centered on UTAUT. Due to the simplicity of these models, influencing factors, and interconnections, the study produced an integrated model in which perceived public service value, citizen e-empowerment, and fear of Covid-19 were investigated. A quantitative research method was utilized to carry out the current study.

To establish the measuring constructs for this study, four specialists were engaged, including e-government specialized academicians and government personnel. Previously validated scales were changed and adjusted to meet with the setting of e-government services and the Vietnamese environment. The public service quality construct was developed from Papadomichelaki and Mentzas (2012), while information quality components were the mixture from the scales of Wang and Liao (2008) and Rehman et al. (2012). Perceived public service value was taken from $\mathrm{Li}$ and Shang (2020). Citizen e-empowerment was derived using the items of Kim and Gupta (2014) and Turunen et al. (2020). Citizen adoption of e-government services were adopted from De Ruyter et al. (2001), whereas citizen intention to suggest construct was generated from the items of Oliveira et al. (2016) and fear of Covid-19 was adapted from the scale of Ahorsu et al. (2020).

The pre-test questionnaire was delivered to 25 respondents to assess the scale's psychometric characteristics, validity, and reliability. Following pretesting, statements were amended in response to comments, and then troublesome indicators were deleted until 37 items remained. The preliminary test was done online in Vietnam with 500 survey respondents who had used e-government services previously. The survey took place over four months, from January to the end of May 2021. The structured questionnaire was distributed to surveyors via email, Facebook Messenger, Zalo Messenger, and Telegram with a web link, and 317 completed surveys were returned. After being cleaned and reviewed, 53.2 percent of 316 clean and completed questionnaires were approved for analysis. Table 1 summarizes the respondents' demographic characteristics. 
Table 1. Demographical analysis $(n=316)$

\begin{tabular}{|c|c|c|c|}
\hline Variables & Category & No & $\%$ \\
\hline \multirow{2}{*}{ Gender } & Male & 137 & $43.35 \%$ \\
\hline & Female & 179 & $56.65 \%$ \\
\hline \multirow{4}{*}{ Age } & $<23$ & 38 & $12.03 \%$ \\
\hline & $23-35$ & 140 & $44.30 \%$ \\
\hline & $36-45$ & 107 & $33.86 \%$ \\
\hline & $>45$ & 31 & $9.81 \%$ \\
\hline \multirow{4}{*}{ Occupation } & Office worker & 125 & $39.56 \%$ \\
\hline & $\begin{array}{l}\text { Non-officer } \\
\text { worker }\end{array}$ & 84 & $26.58 \%$ \\
\hline & $\begin{array}{l}\text { Business owner/ } \\
\text { freelancer }\end{array}$ & 75 & $23.73 \%$ \\
\hline & Others & 32 & $10.13 \%$ \\
\hline \multirow{3}{*}{$\begin{array}{l}\text { Years of using } \\
\text { the internet }\end{array}$} & $<3$ years & 61 & $19.30 \%$ \\
\hline & $3-5$ years & 128 & $40.51 \%$ \\
\hline & $>5$ years & 127 & $40.19 \%$ \\
\hline \multirow{3}{*}{ Household } & Northern region & 110 & $34.81 \%$ \\
\hline & Southern region & 142 & $44.94 \%$ \\
\hline & Central region & 64 & $20.25 \%$ \\
\hline
\end{tabular}

\section{RESULTS}

To move on to the structural model, the measurement model must be evaluated (Hair et al., 2014) with these following indicators: outer loading, Cronbach's alpha, composite reliability, average extracted variance, and discriminant validity (Table 2). The PSQ4, IQ4, CEE3, CEE4, CEE8, CEE10, CEE12, FFC5, CAGS1, and CIR4 outer loadings were less than 0.7 in the PLS approach, resulting in the elimination of ten items from the constructs. Other loadings are more than 0.70 for the remaining 27 items, which all match the convergent validity reliability criterion. Cronbach's alpha (CA) scores for seven components varied from 0.810 to 0.897 , and composite reliability (CR) values of 0.859 to 0.914 fulfilled the criterion for exceptional dependability.

Hair et al. (2014) proposed discriminant validity to examine how items distinguish across conceptions or measure separate ideas. For each variable, the square roots of the AVE should be bigger than the square roots of any of the variables' correlations. As a result, the study used the square roots of AVE coefficients to assess construct validity. All square roots of AVE values are more significant than the correlations in the corresponding columns and rows (Table 3). As a result, all the measures utilized in this study show discriminant validity.

Table 3. Discriminant validity

\begin{tabular}{l|l:l:l:l:l:l:l}
\hline & PGSV & CeE & CAGS & FFC & IQ & CIR & PSQ \\
\hline PGSV & $(0.809)$ & & & & & & \\
\hdashline CeE & 0.571 & $(0.777)$ & & & & & \\
\hdashline CAGS & 0.528 & 0.529 & $(0.818)$ & & & & \\
\hdashline FFC & 0.594 & 0.548 & 0.549 & $(0.851)$ & & & \\
\hdashline IQ & 0.602 & 0.533 & 0.481 & 0.746 & $(0.851)$ & & \\
\hdashline CIR & 0.457 & 0.645 & 0.460 & 0.471 & 0.440 & $(0.859)$ \\
PSQ & 0.552 & 0.574 & 0.766 & 0.698 & 0.551 & 0.491 & $(0.867)$ \\
\hline
\end{tabular}

Next, the paper looked at the multicollinearity of formative structures. The variance inflation factor is used to determine multicollinearity (VIF). According to Hair et al. (2014), a VIF value of more than 5 suggests multicollinearity, whereas a value less than 5 shows no difficulties with multicollinearity. The analysis findings indicate that the lowest VIF value is 1.306 and the highest is 2.816; both values are less than five, indicating that there is no significant collinearity between the predictor constructs in the structural model.

Before appraising the structural model, the study verified its quality by comparing its fit to two model-fitting values - the Standardized Root Mean Square Residual (SRMR), sometimes referred to as the Normed Fit Index (NFI). Hair et al. (2014) state that the appropriate fit standard, SRMR, should be less than 0.08 . The SRMR score of 0.055 - less than the cut-off value of 0.08 - indicates that the model fits well for theory testing.

Table 2. Internal consistency reliability and convergent validity

\begin{tabular}{|c|c|c|c|c|}
\hline Constructs & Outer Loadings & CA & CR & AVE \\
\hline Public service quality - PSQ & $0.837-0.892$ & 0.835 & 0.901 & 0.751 \\
\hline Informational quality - IQ & $0.820-0.882$ & 0.810 & 0.887 & 0.725 \\
\hline Perceived e-government service value - PGSV & $0.802-0.816$ & 0.824 & 0.883 & 0.654 \\
\hline Citizen e-empowerment - CeE & $0.754-0.814$ & 0.897 & 0.914 & 0.603 \\
\hline Fear of Covid-19 - FFC & $0.813-0.866$ & 0.873 & 0.913 & 0.724 \\
\hline Citizen adoption of e-government services - CAGS & $0.759-0.878$ & 0.752 & 0.858 & 0.603 \\
\hline Citizen intention to recommend e-services - CIR & $0.820-0.879$ & 0.821 & 0.901 & 0.751 \\
\hline
\end{tabular}




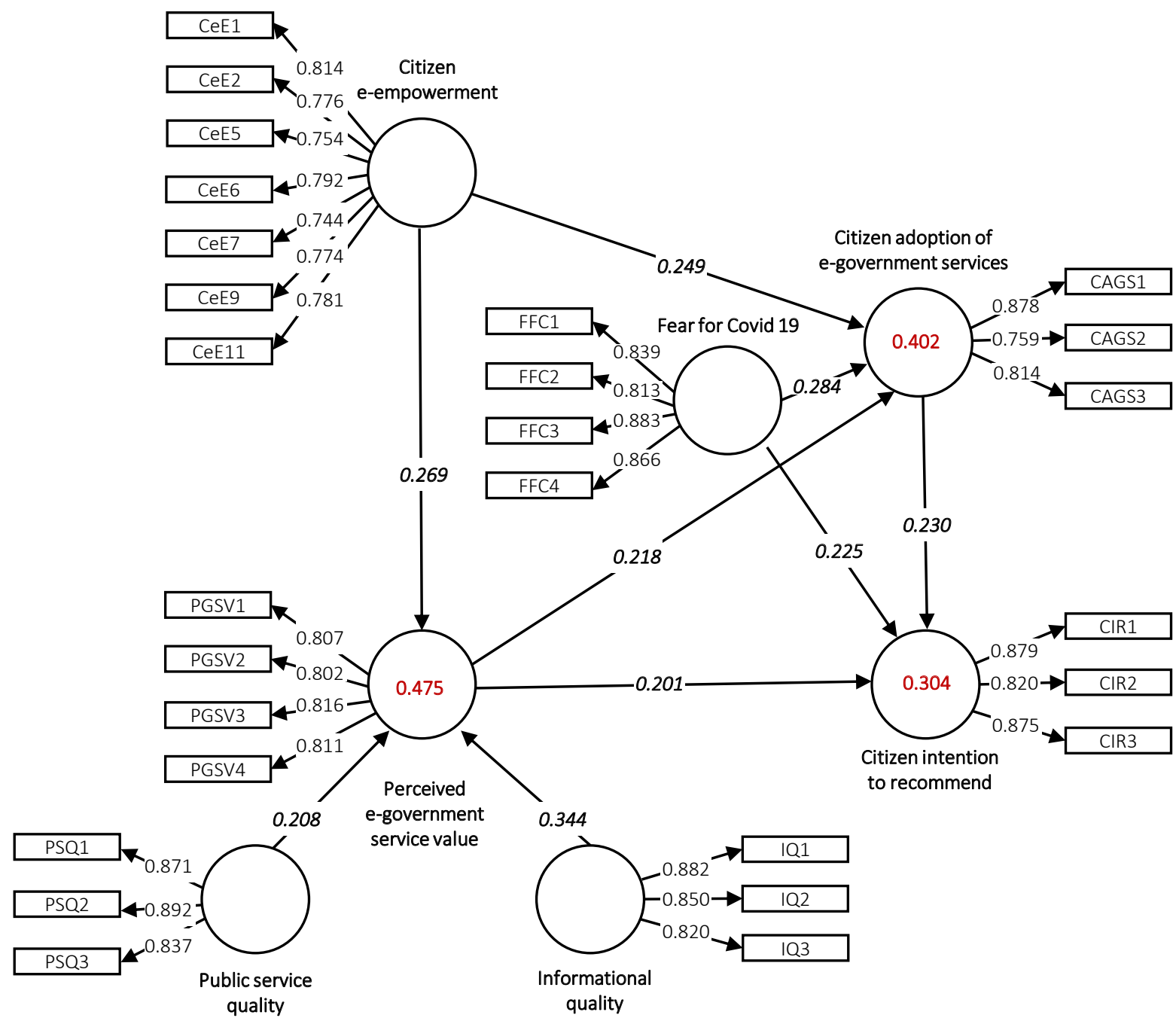

Figure 2. Modeling results

As can be seen in Table 4, the R2 values of PGSV = $0.475, \mathrm{CAGS}=0.402$, and $\mathrm{CIR}=0.304$ correspond to the significant level. The R2 for perceived e-government service value (PGSV) is 0.475 , indicating that 47.5 percent of digital public service engagement is explained by trust in the quality of public services (PSQ) and informative quality (IQ). Furthermore, 40.2 percent of the variance in citizen adoption of e-government services (CAGS) may be explained by perceived e-government service value (PGSV), citizen e-empowerment (CeE), and fear of Covid-19 (FFC). Citizen adoption of e-government services (CAGS), perceived e-government service value (PGSV), and fear of Covid-19 (FFC) account for 30.4 percent of citizens' intention to recommend e-government services (CIR).

The Q2 test was devised to assess endogenous variables' predictive value. If the Q2 value is larger than
0 , the model may be predictive for a dependent construct. As shown in Table 4, all Q2 values of 0.284, 0.339 , and 0.248 are more than zero, indicating that faith in government digitalization, e-participation willingness, and adoption of digital public services all exhibit adequate predictive relevance.

Table 4. R2, Q2, SRMR

\begin{tabular}{l|c:c:c}
\hline $\begin{array}{c}\text { Dependent } \\
\text { variables }\end{array}$ & $\boldsymbol{R 2}$ & $\boldsymbol{Q 2}$ & SRMR \\
\hline PGSV & 0.475 & 0.296 & \\
\hline CAGS & 0.402 & 0.256 & 0.055 \\
\hdashline CIR & 0.304 & 0.217 & \\
\hline
\end{tabular}

The path coefficient is the second criterion for evaluating the structural model. The path coefficients ( $\beta$ values) indicate how each independent variable affects the dependent variable (Gronemus et al., 2010). The path coefficients must be more 
Table 5. Hypotheses testing

\begin{tabular}{|c|c|c|c|c|c|c|}
\hline Hypothesis & Path & $\beta$ & $\mathbf{T}$ & $f^{2}$ & $p$ & Decision \\
\hline$H 1$ & $P S Q$-> PGSV & 0.208 & 3.809 & 0.048 & 0.000 & Accepted \\
\hline $\mathrm{H} 2$ & IQ -> PGSV & 0.344 & 6.909 & 0.141 & 0.000 & Accepted \\
\hline H3 & CeE-> PGSV & 0.269 & 5.998 & 0.083 & 0.000 & Accepted \\
\hline $\mathrm{H} 4$ & $\mathrm{CeE}->\mathrm{CAGS}$ & 0.249 & 4.925 & 0.063 & 0.000 & Accepted \\
\hline H5 & $\mathrm{FFC}>\mathrm{CAGS}$ & 0.284 & 5.071 & 0.078 & 0.000 & Accepted \\
\hline H6 & $F F C->C I R$ & 0.225 & 3.813 & 0.041 & 0.000 & Accepted \\
\hline$H 7$ & PGSV -> CAGS & 0.218 & 3.689 & 0.044 & 0.000 & Accepted \\
\hline H8 & PGSV -> CIR & 0.201 & 3.525 & 0.034 & 0.000 & Accepted \\
\hline H9 & CAGS $->$ CIR & 0.230 & 4.084 & 0.048 & 0.000 & Accepted \\
\hline
\end{tabular}

than 0.100 and significant at the 0.05 level to account for the model effect. The results in Table 5 indicate that each independent variable influences the dependent variables. The highest link in the model is between informative quality and perceived e-government service value $(\beta=0.344)$, whereas the poorest relationship is between perceived e-government service value and citizen intention to suggest e-government services $(\beta=$ 0.201). Additionally, all nine hypotheses are validated by the p-value. Along with R2, the size of the effect (f2 analysis) is used to examine if substantial changes in the endogenous latent variable occur when a given exogenous variable is deleted from the model. According to Cohen (1988), values of $\mathrm{f} 2$ of $0.02,0.15$, and 0.35 indicate small, medium, and large effects, respectively.

\section{DISCUSSION}

The analysis results indicated four following dominant observations. At first, citizen adoption of e-government services has been positively impacted by perceived e-government service value, citizen e-empowerment, and fear of Covid-19. Fear of Covid-19 was found to be substantial and the biggest predictor of citizen uptake of e-government services. This conclusion is similar to Raza et al. (2021) who found that social separation by the Covid-19 pandemic had the most meaningful influence on students' LMS acceptance. Second, the verified correlations between public service quality, informational quality, and perceived e-government service value are together with the results of Jaradat et al. (2018) and Hung et al. (2006). A citizen's view of e-government service is naturally dependent on the experience with consumable services and information from e-government websites. Third, the citizen e-empowerment is investigated under four essential dimensions: e-com- petence, e-meaning, e-impact, and e-self-determination. The favorable effect of citizen e-empowerment on citizen adoption of e-government services is consistent with the findings of Naranjo-Zolotov et al. (2019). Fourth, the perceived e-government service value, fear of Covid-19, and citizen adoption of e-government services favorably affect citizen intentions to recommend such services. Among three predictors, the citizen acceptance of e-government services had the most considerable influence. This finding corroborated Oliveira et al. (2016).

This paper conceptually contributes to the body of knowledge on e-government in three ways. The first theoretical conclusion stems from the establishment of an integrated research methodology for analyzing citizen uptake of e-government services and citizen intention to endorse them. Along with the usual incentive of perceived e-government service value addressed in earlier research, the analyzed model included the citizen e-empowerment - an inner person foundation. Second, the paper expanded the concept of e-empowerment in the context of e-government by proposing four revised empowerment dimensions: e-competence, e-meaning, e-impact, and e-self-determination. Thirdly, the positive correlation between citizen e-empowerment and citizen use of e-government services entails the following: (a) e-competence - the more skills with online service the citizens have, the greater the level of e-government services they adopt; (b) e-meaning - when citizens realize the value of using e-government service to their lives and businesses, they assume these kinds of services; (c) e-impact - in case citizens understand and foresee the positive outcomes of the e-government service to the whole society development, they are willing to adopt these services; (d) e-self-determination - with a higher perception of self-responsibility, citizens are motivated to adopt e-government services. 
In practice, this study made three recommendations. To begin, fear of Covid-19 has a large and critical effect on citizen adoption of e-government services, as well as a direct positive effect on citizen intention to suggest e-government services. Thus, the government should seize the chances presented by the Covid-19 pandemic to promote e-government services to people. The example of the Covid-19 tracking program exemplifies this consequence perfectly. Second, enhancing public service quality and informational quali- ty is critical and vital to adopting e-government services. The quality of information released on the government's official online portals should be regular and accurate, as well as easily accessible. Thirdly, from the perspective of citizen e-empowerment, all citizens should be educated about the outcomes, values, self-responsibility, and working procedures of e-government services to fully equip citizens with the knowledge, information, and skills necessary to use e-government services.

\section{CONCLUSION}

Studying the relationships between citizen perceptions of e-government services, citizen empowerment, fear of Covid-19, citizen adoption of e-government services, and citizen suggestion of e-government services are the key goals of this study. This study develops the formative structure of adoption of e-government services employing data acquired from 316 clean and authentic answers from 500 questioned respondents dwelling throughout Vietnam.

Unlike earlier research in this area, which has largely focused on TAM, UTAUT, and technology acceptance models, this study established an integrated research model with both e-government service quality and citizen empowerment. PLS analysis with Smart PLS software was used to evaluate the measurement model and structural model.

The research findings suggested that perceived e-government service value, citizen e-empowerment, and fear of Covid-19 all had a good influence on citizen adoption of e-government services. Other factors that drove the decision to offer e-government services include the value that citizens see in them, their apprehension about Covid-19, and their use of e-government services. Additionally, the perceived value of e-government services was greatly impacted by the quality of public services, the quality of information, and perceived e-empowerment. The findings of this study have three new contributions to the body of knowledge as well as three practical consequences. This study has some limitations that should be addressed in future research, including the following: the sample size was limited to 316 respondents, the survey approach was the only method employed, and further field and experimental investigations should be combined.

\section{AUTHOR CONTRIBUTIONS}

Conceptualization: Hai Ninh Nguyen, Manh Dung Tran.

Data curation: Hai Ninh Nguyen.

Formal analysis: Hai Ninh Nguyen, Manh Dung Tran.

Investigation: Hai Ninh Nguyen.

Methodology: Manh Dung Tran.

Project administration: Manh Dung Tran.

Software: Hai Ninh Nguyen.

Supervision: Manh Dung Tran.

Validation: Hai Ninh Nguyen.

Visualization: Hai Ninh Nguyen.

Writing - original draft: Hai Ninh Nguyen.

Writing - review \& editing: Hai Ninh Nguyen, Manh Dung Tran. 


\section{REFERENCES}

1. Ahorsu, D. K., Lin, C. Y., Imani, V., Saffari, M., Griffiths, M. D., \& Pakpour, A. H. (2020). The fear of COVID-19 scale: development and initial validation. International journal of mental health and addiction. https://dx.doi.org/10.10 07\%2Fs11469-020-00270-8

2. Bandura, A. (1986). Social foundations of thought and action: A social cognitive theory. Englewood Cliffs, NJ: Prentice Hall.

3. Bannister, F., \& Connolly, R. (2014). ICT, public values and transformative government: A framework and programme for research. Government Information Quarterly, 31(1), 119-128. https:// doi.org/10.1016/j.giq.2013.06.002

4. Bellamy, C., \& Taylor, J. A. (1998). Understanding government. Information infrastructure and policy, 6(1), 1-16.

5. Castelnovo, W. (2013). A stakeholder-based approach to public value. Proceedings of the 13th European Conference on eGovernment, 94-101.

6. Chen, T. Y., Chang, P. L., \& Yeh, C. W. (2004). A study of career needs, career development programs, job satisfaction and the turnover intentions of $\mathrm{R} \& \mathrm{D}$ personnel. Career development international, 9(4), 424-437. https://doi. org/10.1108/13620430410544364

7. Cohen, J. (1988). Statistical power analysis for the behavioral sciences. Hillsdale, NJ: Lawrence Erlbaum.

8. De Ruyter, K., Wetzels, M., \& Kleijnen, M. (2001). Customer adoption of e-service: an experimental study. International journal of service industry management, 12(2), 184-207. https://doi. org/10.1108/09564230110387542

9. El-Haddadeh, R., Osmani, M., Hindi, N., \& Fadlalla, A. (2021). Value creation for realising the sustainable development goals: Fostering organisational adoption of big data analytics. Journal of Business Research, 131, 402410. https://doi.org/10.1016/j. jbusres.2020.10.066
10. Ergeneli, A., Arı, G. S., \& Metin, S. (2007). Psychological empowerment and its relationship to trust in immediate managers. Journal of business research, 60(1), 41-49. https://doi.org/10.1016/j. jbusres.2006.09.012

11. Frow, P., \& Payne, A. (2007). Towards the 'perfect' customer experience. Journal of Brand Management, 15(2), 89-101. http:// dx.doi.org/10.1057/palgrave. bm. 2550120

12. Füller, J. (2010). Refining virtual co-creation from a consumer perspective. California management review, 52(2), 98-122. https://doi. org/10.1525/cmr.2010.52.2.98

13. Grimsley, M., \& Meehan, A. (2007). e-Government information systems: Evaluation-led design for public value and client trust. European Journal of Information Systems, 16(2), 134-148. https://doi.org/10.1057/palgrave. ejis.3000674

14. Gronemus, J. Q., Hair, P. S., Crawford, K. B., Nyalwidhe, J. O., Cunnion, K. M., \& Krishna, N. K. (2010). Potent inhibition of the classical pathway of complement by a novel C1q-binding peptide derived from the human astrovirus coat protein. Molecular immunology, 48(1-3), 305-313. https://doi.org/10.1016/j.molimm.2010.07.012

15. Grönroos, C. (1984). A service quality model and its marketing implications. European Journal of marketing, 18(4), 3644. https://doi.org/10.1108/ EUM0000000004784

16. Hair Jr, J. F., Sarstedt, M., Hopkins, L., \& Kuppelwieser, V. G. (2014). Partial least squares structural equation modeling (PLS-SEM): An emerging tool in business research. European business review, 26(2), 106-121. https://doi. org/10.1108/EBR-10-2013-0128

17. Halvorsrud, R., Kvale, K., \& Følstad, A. (2016). Improving service quality through customer journey analysis. Journal of service theory and practice, 26(6), 840-867.
https://doi.org/10.1108/JSTP-052015-0111

18. Hung, S. Y., Chang, C. M., \& Yu, T. J. (2006). Determinants of user acceptance of the e-Government services: The case of online tax filing and payment system. Government information quarterly, 23(1), 97-122. http://dx.doi.org/10.1016/j. giq.2005.11.005

19. Jaradat, M. I. R. M., Moustafa, A. A., \& Al-Mashaqba, A. M. (2018). Exploring perceived risk, perceived trust, perceived quality and the innovative characteristics in the adoption of smart government services in Jordan. International Journal of Mobile Communications, 16(4), 399-439. http://dx.doi. org/10.1504/IJMC.2018.092669

20. Kim, H. W., \& Gupta, S. (2014). A user empowerment approach to information systems infusion. IEEE Transactions on Engineering Management, 61(4), 656-668. http://doi.org/10.1109/ TEM.2014.2354693

21. Kumar, V., Mukerji, B., Butt, I., \& Persaud, A. (2007). Factors for successful e-government adoption: A conceptual framework. Electronic Journal of E-government, 5(1).

22. Lean, O. K., Zailani, S., Ramayah, T., \& Fernando, Y. (2009). Factors influencing intention to use e-government services among citizens in Malaysia. International journal of information management, 29(6), 458-475. https://doi.org/10.1016/j. ijinfomgt.2009.03.012

23. Li, Y., \& Shang, H. (2020). Service quality, perceived value, and citizens' continuous-use intention regarding e-government: Empirical evidence from China. Information \& Management, 57(3), 103197. http://dx.doi.org/10.1016/j. im.2019.103197

24. Lu, L., Lu, A. C. C., Gursoy, D., \& Neale, N. R. (2016). Work engagement, job satisfaction, and turnover intentions: A comparison between supervisors and line-level employees. International Journal of Contemporary 
Hospitality Management, 28(4), 737-761. https://doi.org/10.1108/ IJCHM-07-2014-0360

25. K., \& Zahide, F. (2002). The measurement of web-customer satisfaction: An expectation and disconfirmation approach. Information Systems Research, 13(3), 296-315. https://doi.org/10.1287/ isre.13.3.296.76

26. Mensah, I. K. (2019). Factors influencing the intention of university students to adopt and use e-government services: An empirical evidence in China. SAGE Open, 9(2). https://doi. org/10.1177/2158244019855823

27. Moore, M. H. (1995). Creating public value: Strategic management in government. Harvard university press.

28. Naranjo-Zolotov, M., Oliveira, T., \& Casteleyn, S. (2019). Citizens' intention to use and recommend e-participation: Drawing upon UTAUT and citizen empowerment. Information Technology \& People, 32(2), 364-386. https://doi. org/10.1108/ITP-08-2017-0257

29. Ndou, V. (2004). E-Government for developing countries: opportunities and challenges. The electronic journal of information systems in developing countries, 18(1), 1-24. https://doi. org/10.1002/j.1681-4835.2004 tb00117.x

30. OECD. (2019). Strengthening Digi tal Government. Retrieved June 1, 2021, from https://www.oecd. org/going-digital/strengtheningdigital-government.pdf

31. Oliveira, T., Thomas, M., Baptista, G., \& Campos, F. (2016). Mobile payment: Understanding the determinants of customer adoption and intention to recommend the technology. Computers in human behavior, 61, 404-414. https://doi. org/10.1016/j.chb.2016.03.030

32. Papadomichelaki, X., \& Mentzas, G. (2012). e-GovQual: A multipleitem scale for assessing e-government service quality. Government information quarterly, 29(1), 98-109. https://doi.org/10.1016/j. giq.2011.08.011

33. Peterson, N. A. (2014). Empowerment theory: Clarifying the nature of higher-order multidimensional constructs. American journal of community psychology, 53(1-2), 96-108. http://doi.org/10.1007/ s10464-013-9624-0

34. Raza, S. A., Qazi, W., Khan, K. A., \& Salam, J. (2021). Social isolation and acceptance of the learning management system (LMS) in the time of COVID-19 pandemic: an expansion of the UTAUT model. Journal of Educational Computing Research, 59(2), 183-208. https://doi.org /10.1177\%2F0735633120960421

35. Rehman, M., Esichaikul, V., \& Kamal, M. (2012). Factors influencing e-government adoption in Pakistan. Transforming Government: People, Process and Policy, 6(3), 258-282. https://doi. org/10.1108/17506161211251263

36. Shankar, A., \& Datta, B. (2018) Factors affecting mobile payment adoption intention: An Indian perspective. Global Business Review, 19(3_suppl), S72-S89. https://doi. org/10.1177/0972150918757870

37. Shareef, M. A., Kumar, V., Kumar, U., \& Dwivedi, Y. K. (2011). eGovernment Adoption Model (GAM): Differing service maturity levels. Government information quarterly, 28(1), 17-35. https://doi. org/10.1016/j.giq.2010.05.006

38. Sjoberg, F. M., Mellon, J., \& Peixoto, T. (2017). The effect of bureaucratic responsiveness on citizen participation. Public Administration Review, 77(3), 340351. Retrieved from https://www. oidp.net/docs/repo/doc381.pdf

39. Spreitzer, G. M. (1995). Psychological empowerment in the workplace: Dimensions, measurement, and validation. Academy of management Journal, 38(5), 14421465. Retrieved from https://www. jstor.org/stable/256865

40. Thomas, K. W., \& Velthouse, B. A. (1990). Cognitive elements of empowerment: An "interpretive" model of intrinsic task motivation. Academy of management review, 15(4), 666-681. https://doi. org/10.2307/258687

41. Turunen, L. L. M., Cervellon, M. C., \& Carey, L. D. (2020). Selling second-hand luxury: Empower- ment and enactment of social roles. Journal of Business Research, 116, 474-481. https://doi. org/10.1016/j.jbusres.2019.11.059

42. Twizeyimana, J. D., \& Andersson, A. (2019). The public value of E-Government - A literature review. Government information quarterly, 36(2), 167-178. https:// doi.org/10.1016/j.giq.2019.01.001

43. United Nations. (2020). The Impact of Digital Technologies. Retrieved June 1, 2021, from https:// www.un.org/en/un75/impactdigital-technologies

44. Vinzi, V. E., Trinchera, L., \& Amato, S. (2010). PLS path modeling: from foundations to recent developments and open issues for model assessment and improvement. In E. V. Vinzi, W. Chin, J. Henseler, \& H. Wang (Eds.), Handbook of partial least squares (pp. 47-82). Springer, Berlin, Heidelberg. https://doi. org/10.1007/978-3-540-32827-8_3

45. Wang, Y. S., \& Liao, Y. W. (2008). Assessing eGovernment systems success: A validation of the DeLone and McLean model of information systems success. Government information quarterly, 25(4), 717-733. https://doi.org/10.1016/j. giq.2007.06.002

46. Wilder-Smith, A., \& Freedman, D. O. (2020). Isolation, quarantine, social distancing and community containment: pivotal role for old-style public health measures in the novel coronavirus (2019$\mathrm{nCoV}$ ) outbreak. Journal of travel medicine, 27(2), taaa020. https:// doi.org/10.1093/jtm/taaa020

47. Zimmerman, M. A., \& Rappaport, J. (1988). Citizen participation, perceived control, and psychological empowerment. American Journal of community psychology, 16(5), 725-750. https://doi.org/10.1007/ bf00930023 